\title{
LEADER AS A EUROPEAN POLICY FOR RURAL DEVELOPMENT IN A MULTILEVEL GOVERNANCE FRAMEWORK: A COMPARISON OF THE IMPLEMENTATION IN FRANCE, GERMANY AND ITALY
}

Kim Pollermann ${ }^{1}$, Francis Aubert ${ }^{2}$, Marielle Berriet-Solliec ${ }^{3}$, Catherine Laidin ${ }^{4}$, Denis Lépicier ${ }^{5}$, Hai Vu Pham ${ }^{6}$, Petra Raue ${ }^{7}$, Gitta Schnaut ${ }^{8}$

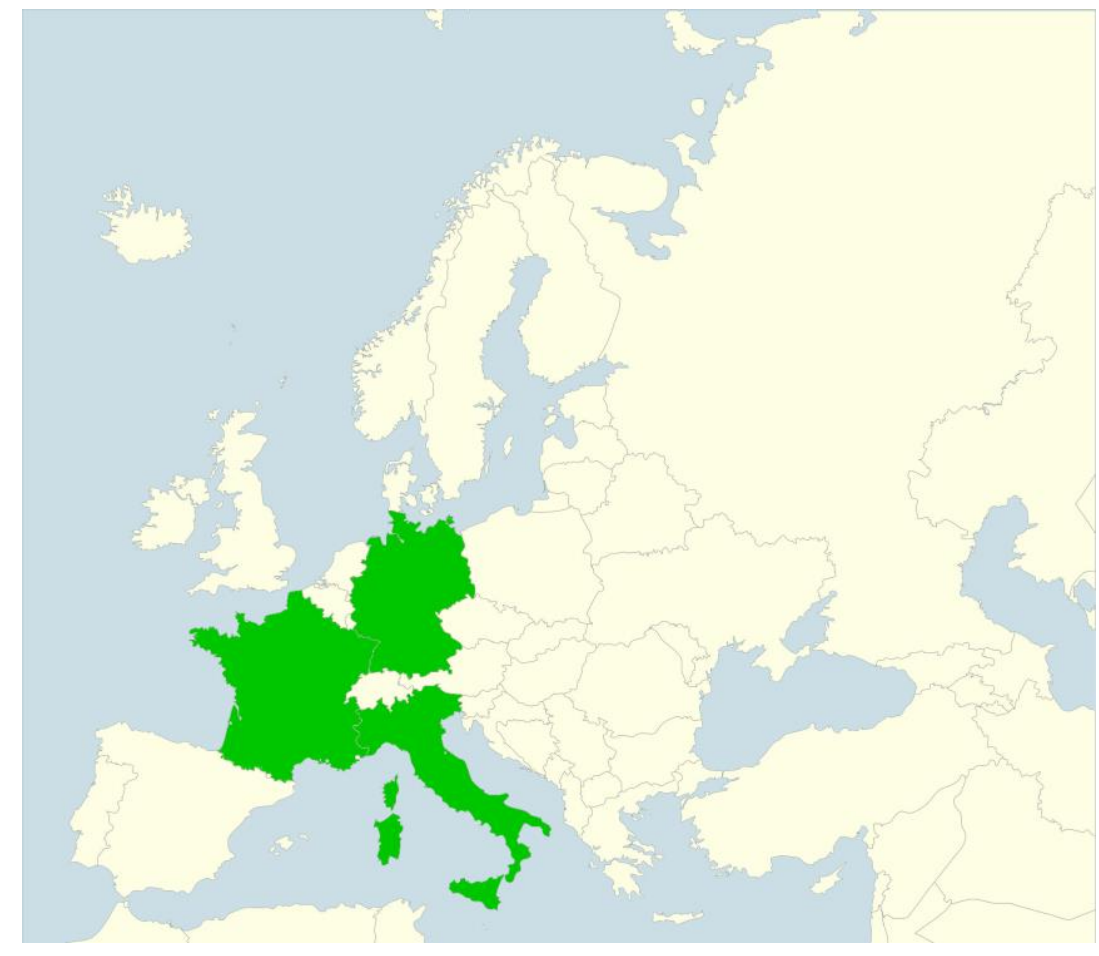

\footnotetext{
1 Kim Pollermann, Thünen Institute of Rural Studies, Braunschweig, Germany, ORCID: 0000-0002-6158-0577, e-mail: kim.pollermann@thuenen.de

2 Francis Aubert, CESAER, AgroSup Dijon, INRA, Univ. Bourgogne Franche-Comté, Dijon, France, ORCID: 00000001-8298-3423, e-mail: francis.aubert@inrae.fr

3 Marielle Berriet-Solliec, CESAER, AgroSup Dijon, INRA, Université. Bourgogne Franche-Comté, Dijon, France, ORCID: 0000-0003-4581-9792, e-mail: marielle.berriet-solliec@agrosupdijon.fr

${ }^{4}$ Catherine Laidin, Agrocampus Ouest, UMR6590 ESO, Rennes; Université de Rennes 1, UMR6051 CRAPE, IEP, Rennes, France, ORCID: 0000-0003-3097-7579, e-mail: catherine.laidin@agrocampus-ouest.fr

5 Denis Lépicier, CESAER, AgroSup Dijon, INRA, Université Bourgogne Franche-Comté, Dijon, France, ORCID: 0000-0003-1366-3543, e-mail: denis.lepicier@inra.fr

${ }^{6}$ Hai Vu Pham, CESAER, AgroSup Dijon, INRA, Université Bourgogne Franche-Comté, Dijon, France, ORCID: 00000002-7911-6852, e-mail: hai-vu.pham@dijon.inra.fr

7 Petra Raue, Thünen Institute of Rural Studies, Braunschweig, Germany, e-mail: petra.raue@thuenen.de

${ }^{8}$ Gitta Schnaut, Thünen Institute of Rural Studies, Braunschweig, Germany
} 
Abstract: Parts of European rural development policies are meant to empower local decision makers. These policies are implemented in very different multilevel governance contexts in the member states. We question the extent to which the institutional differences at the different levels affect the implementation of LEADER (an approach for Community-led Local Development). This contributes to a better understanding of the causes and consequences of different types of LEADER implementation. The research is based on ten case studies in France, Germany and Italy. First, there is an examination of the three different administration systems and the variations of Rural Development Programmes. Based on analyses of documents and interviews with stakeholders, we analysed institutional differences in the LEADER implementation at local level.

Key words: rural development, multilevel governance, European policy, LEADER, France, Germany, Italy, Community-led Local Development

\section{Introduction}

'Europe of the Regions' is a popular metaphor employed in the political debate about the future development of the European Union (EU). A "Europe of the Regions" seems to offer solutions to improve the transparency of decision-making and a decentralization of competences (Tömmel 1998). Agricultural and rural issues are affected by this institutional reorganization (Perraud, 2001; Berriet-Soliec and Trouvé, 2010). The EU uses different approaches to support regional development. To address especially rural areas, the EU contributes to the set-up and funding for Rural Development Programmes (RDPs). LEADER, as one part of this European policy, aims to empower local decision-makers and to support the development of strategies at a subregional level to meet specific challenges of the territory (Chevalier and Dedeire, 2014, Lacquement et al., 2013). LEADER is an acronym derived from the French: Liaisons entre Actions de Développement de l'Economie Rurale, which means links between actions for the development of the rural economy.

LEADER started in 1991 as an EU Community Initiative Programme. Launched as an experimental "pilot" scheme under LEADER I in the first period 1991-94, in the following period (1995-99) LEADER II focused on the "laboratory" aspect, making use of the momentum to engage innovative pathways, the program was still mainly limited to disadvantaged rural areas. During 2000-06, all rural areas were eligible for LEADER+. In the last funding period (2007-13), LEADER was "mainstreamed". It was integrated into the RDP as a horizontal priority "axis" under which all RDP measures should be eligible for funding (Oedl-Wieser et al., 2010, Pollermann et al., 2013). In 2014-20, there is again a new edition of LEADER. It is now offered for all structural funds as Community-led Local Development (CLLD), hence covering all EU areas (rural/urban/coastal). Thus, CLLD aims to extend the participative LEADER approach to other EU funds. But in fact, as there was no obligation in the structural funds (EFRD and ESF) to include CLLD as a measure in the member states programmes, implementation of multi-fund CLLD was limited.

LEADER is in general designed with decision-making at the local level, whereby a Local Action Group (LAG) composed of stakeholders from local government, civil society and business implements its local development strategy (LDS) with its own budget to fund projects (Navarro et al. 2015). LEADER is supposed to improve local governance and thus promote local development. A set of LEADER principles describes the characteristics of LEADER: Territorial approach, bottom-up, public-private partnership, integrated and multi-sectoral approach, innovation, cooperation with other regions, networking (EU-Com 2006; Pollermann 2016).

The main assumption of LEADER is that rural support measures become more effective if decision-making and implementation are embedded locally. Nevertheless, it is not easy to convincingly demonstrate this assumed added value of the LEADER approach, even though 
some researchers tried to test approaches to estimate this added value (Berriet-Solliec et al., 2017, Thuesen \& Nielsen 2014). The diverse and scattered evidence might partly be due to the context dependence of implementation and success of LEADER at local level.

As the LEADER approach is about cooperation of private and public actors, it is important to understand the influence of the institutional settings towards a successful LEADER implementation. Different levels are relevant, from general administrative frameworks over differences in RDPs to local institutions, so LEADER is put into practice within a multilevel governance framework (Pollermann et al. 2014).

Thus, the aim of the article is to generate more knowledge about conditions of LEADER implementation and their influence on the modalities of cooperation between local actors and on their ability to better respond to territorial development issues. Accordingly, we question the:

(1) Influence of differences in framework conditions and administrative systems on the national level (chapter 4)

(2) Influence of differences in the design of Rural Development Programmes (chapter 5)

(3) way in which these different boundary conditions, together with local administrative environments, affect the LEADER implementation on the local level (chapter 6).

Regarding national differences, we have chosen three EU Member States with different traditions and institutional frameworks: France, Germany and Italy.

The findings of the article result from the European research programme Trustee $^{9}$ that focused on rural synergies and trade-offs between economic development and ecosystem services.

\section{Theoretical background}

The scientific examination of LEADER relies on different theories in the context of regional development and explanations of governance issues (to structure the LAG as a core of a governance arrangement). In fact, the understanding of the LEADER-approach is closely related to development theories of a neo-endogenous development (Cejudo and Navarro 2020; Konečný 2019; Bosworth et al, 2016; Dax et al. 2016). As LEADER has the particularity of being a local development programme built at the European level, the modalities of interlinkage within such a scheme are also relevant. Therefore, for the operationalisation in this article, we put our attention on the governance side and the next chapter will display LEADER in the light of multilevel-governance.

\subsection{Multi-level governance framework}

A variety of theoretical and empirical studies elaborate that governance systems encompass multiple levels, either within an organization or across hierarchical units of government (Meyer et al. 2004, 31). In LEADER, patterns of implementations can be seen as embedded in a multilevel governance system. Thus, our research approach is based on theories of multilevel governance (Bache and Flinders, 2004, Laidin, 2019, Meyer et al., 2004, Pollermann et al., 2014a, Kuhlmann, 2014). In this article, the term "Governance" is used in an analytical sense: not focused on a normative perspective like in good governance concepts, nor with a narrow definition as self-governance. The term "Governance" highlights the regulation of collective actions with different modes of steering, enabling a cooperation of actors from state, economy and civil-society (Politt and Bouckaert, 2011). Typical actors in governance arrangements are shown in Figure 1.

\footnotetext{
9 http://www.trustee-project.eu/. The research has received funding from the European Union by the European Commission within the Seventh Framework Programme in the frame of RURAGRI ERA-NET under Grant Agreement $n^{\circ} 235175$ TRUSTEE (project $n^{\circ}$ ANR-13-RURA-0001-01).
} 


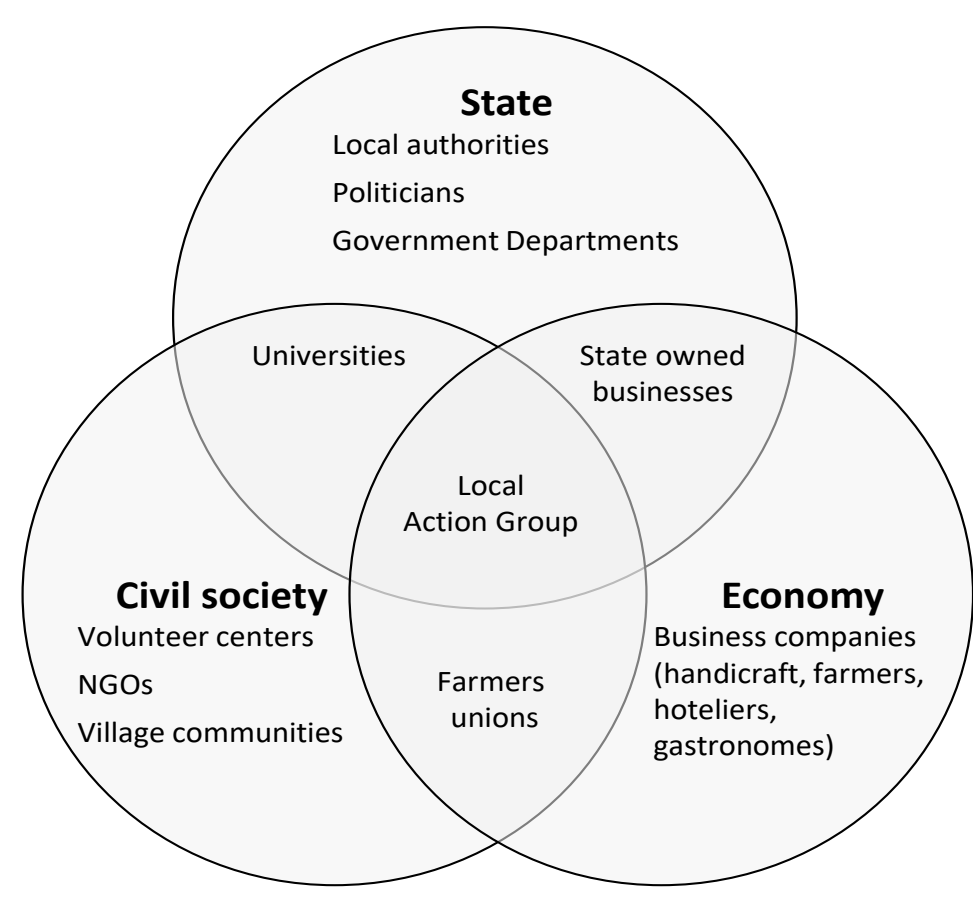

Fig 1. Groups of actors in a rural governance arrangement. Source: based on Fürst et al. (2006)

Looking at rural development in general, and more specifically at LEADER, the concept of Multilevel governance describes the institutional, regulatory and procedural environment as external circumstances for the operation of LEADER. Those circumstances can greatly influence the style of interaction between (and within) different levels and institutions, the degree of autonomy of the local level, the administrative procedures applied, and the autonomy of local partnership (Grieve et al. 2010, 22). Important parts of this framework are the funding conditions set for LEADER at the European level and put into practice at national and subnational level on the one hand, and the public administrative system setting the course for the manoeuvre of local public entities on the other hand (Figure 2 shows relevant levels in LEADER context).

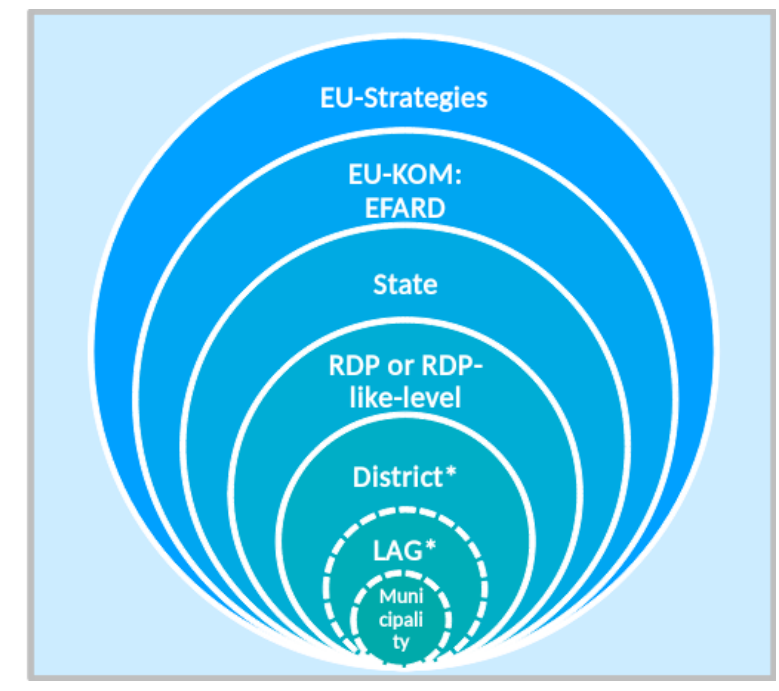

Fig 2. Levels of a multilevel governance framework for LEADER. Source: Berriet-Solliec et al. $2015^{10}$

Each level has an influence on the work of the LAGs. At the European level, for example, there is a regulation that not more than $50 \%$ of LAG members may come from the public sector

${ }^{10}$ A LAG can be part of a district, but it can as well cover a whole district or be composed of parts from two or even three districts. 
(regulation in funding period 2007-13). At the national level, there were consultations to safeguard procedures for decision-making to avoid conflicts of interests. Some managing authorities make rules, like a minimum of 10 members in each decision making body, which was not regulated at European level. At the LAG-level, there are typically different modes of selfrecruitment, often with a special role for public authorities. Altogether, the role of local government in local LEADER implementation depends on the administrative systems. Specifically, the local level of administration plays a crucial role. Regarding institutions at the local level, there are large differences between different countries. For example, in Germany, there is a strong history of a local self-administration of municipalities. In France, the municipalities used to be a very strong level of local public policy, but since 1992, more and more of their competencies have been transferred to inter-municipalities (Thoenig, 2005).

\subsection{Literature review: Findings about LEADER in different Member States}

As there is a long history of LEADER implementation, there is also broad experience with research about LEADER. An overview about literature is presented in Pollermann et al. (2014a).

Overall, in the literature, there are positive assessments regarding fields like better cooperation, participation of local stakeholders (but not all groups of a population), networking, linkage between different types of knowledge and suitable projects fitting to the local areas (Navarro et al. 2018, Bosworth et al. 2016, Pollermann et al. 2014, Laidin and Berriet-Soliec, 2016; Dargan and Shucksmith 2008). Thereby, the different elements of LEADER lead to an added value (Thuesen and Nielsen 2014). For the success of LEADER, it is crucial to have a network of actors with a high commitment to the territory as Navarro et al. (2018) highlighted for the case of developing innovations. An evaluation report with ten case studies from ten European countries summarises "The implementation of the LEADER method promoted multi-sectoral and integrated development and contributed to strengthening the local economy and the social capital in rural areas" (Metis et al. 2010, 15). Besides such positive assessments, the often reported problems are constraints due to too bureaucratic framework and threats to the bottomup approach through dominance from the public sector (Pollermann and Raue 2020, Thuesen 2010).

As LEADER effects differ between countries, as well as between funding periods, generalisations are not possible. "As reflected in the large and growing literature, LEADER effects are so different between regions and countries that any transnational or trans-regional generalization is likely to be unreliable" (Papadopoulou et al. 2011, 672). Also, due to this heterogeneity, it is still difficult to judge the real impact on socio-economic development (ECA 2010). A look at the entire specific multilevel framework is needed to understand LEADER implementation.

To gain insights about such relations, there are already some studies focusing on the international geographical comparisons. Kull (2014) has investigated the multi-level governance in the LEADER+ programme in Germany and Finland, and Rizzo (2013) has carried out an institutional comparison between LEADER implementation of two regions in Finland and Italy. Dax et al. (2016) examined opportunities for innovation in Austria and Ireland. Chevallier et al. (2017) elaborate analyses between Lithuania and France (2017). Cavazzani \& Moseley (2001) included eight EU countries and focused on the effectiveness of partnerships on rural development.

Regarding our three questions from the introductory chapter, we want to highlight the following findings from literature:

\section{Framework conditions and administrative systems:}

Obviously, the style of interaction between (and within) different levels and institutions of the development system and the degree of autonomy of the local level are crucial framework conditions. The general differences between France, Germany and Italy are known from literature about the political and administrative systems. The three countries show significant differences in terms of political and administrative organisation and the decentralisation of 
power. Some convergence can be observed as they all are "old" Member States of the European Union and are concerned with similar concepts and discourse on administrative reforms. But the concrete decisions and practical implementations tend to follow countryspecific peculiarities and path dependencies (Kuhlmann and Wollmann, 2014). All three systems are shaped by the traditional continental European model of "rule of law," as opposed to the Anglo-Saxon "public interest culture" (Berriet-Solliec et al 2016). The traditional system of France and Italy is characterized by a strong centralised government and a powerful centralised bureaucracy, which is sectorally organised from the central to the local level (Pollermann and Raue 2020). These conditions define the tasks, competences and resources as well as the way of interaction between different units of public administration and between public administration and society. Therefore, this article has the task to make such insights about similarities and differences in the context of rural development more precise and to elucidate their influence on LEADER at local level. A compilation of literature helps to present the differences:

- In conditions and challenges in rural areas in the three countries, and

- in the basic settings of the administrative systems.

\section{Design of the Rural Development Programmes:}

The RDP transforms the frame set by the EAFRD regulation into funding measures, rules and procedures for project implementation. The RDPs are established by Member States at the national level or in federal states at subnational levels. In the context of our case studies, there are 9 different relevant RDPs.

Concerning LEADER, the RDP contain the procedures for selection of LAG applications and guidelines for project approval. In theory, the RDP regulations for LEADER should enable a bottom-up approach but the literature reports some top-down influences. Different authors see a gap between the idea of local governance implicit in the formal rules of the LAG and the actual mode of local governance and the ability to innovate (Chevalier and Vollet 2019).

Fekete (2014) indicates that the LEADER principles in Hungary have disregarded in many respects: "excessive central governance, political party influence, excessive bureaucracy, the lack of funds [...]. Communities play a less-important-than-expected role" (Fekete 2014).

The RDP design can as well facilitate a dominance of the agricultural sector, also regarding the kind of selected projects. This was observed in Austria for the funding period 2007-2013 (Dax et al. 2013; further assessments for different countries: Konečný 2019). Standard agricultural projects were distributed via email to members of the LEADER committee for (tacit) approval within a short period (1-2 weeks). In other words, the decision-making bodies only "rubber-stamp" such projects (Oedl-Wieser et al. 2010).

A detailed literature review on RDP influences focussing on the ability of LEADER to create innovative approaches is presented by Navarro et al. (2018). Especially, the mainstreaming of LEADER in the funding period 2007-13 is rated negatively in a sense of potentially diminished contributions to innovation. Although the principles of LEADER have not been eliminated, their relevance has been restricted. Despite these negative influences from mainstreaming, there is no doubt that a significant increase in the size of the budget and a more comprehensive integration of LEADER into the main RDP structure have upgraded LEADER's status, shifting the programme from the margins towards the centre of rural policy (Dax et al. 2016).

\section{LEADER implementation at local level:}

A crucial point in studies about LEADER is usually cooperation within the LEADER governancearrangements, but less attention has been given up till now to the interdependency between (local) government and governance in those partnerships (Pollermann and Raue 2020). More frequent are insights on the role of public actors in the LAGs itself. An example from LEADER in Poland: "local officials were afraid that the partnership may be used to create an alternative decision-making centre. For instance, there were some cases that local politicians created 
associations and/or foundations that later became a part of a partnership as a non-public actor. This way, they tried to assure a majority in the partnership" (Falkowski 2013: 77). In Denmark, Teilmann and Thuesen (2014) show that the municipalities are also seen as valuable partners in fulfilling the LAG objectives; however, it is difficult to define the inflection point at which municipalities become too dominant and come into conflict with the rationale behind the LEADER approach to self-governance. Other case studies in France, Lithuania and Spain also show a "conflict of legitimacy" as some elected representatives contest the legitimacy of decision making on public funds by committees composed of unelected private actors. In the end those case studies underpinned that local structures are very important for a successful implementation: "expected positive effects in terms of innovation under LEADER are closely dependent on the structure of networks of actors and arrangements between them at the local level" (Chevalier and Vollet 2019). Dargan \& Shucksmith (2008) highlighted the role of experiences with collective action, when they state for Calabria in Italy: most actors still work separately from others rather than collectively because of their lack of trust in collective action.

For further research, it should be taken into account that the exemplified international differences are hard to judge because the findings often rely on different methodological approaches. For example, a (negative) political top-down influence seems to be more problematic in Hungary or Austria, but less problematic in Germany. Is it possible that some studies just have been more effective in detecting such influences due to different research approaches or just the focus of surveys? For our research it will be beneficial to use the identical research approach in the context of different RDP designs and framework conditions (in France, Italy and Germany).

Against this background, there is still a research gap in the knowledge about the specific ways administrative and RDP-frameworks influence LEADER implementation. Thus, more knowledge can be created with a comparative analysis of the modalities of the LEADER implementation at the national, regional and local levels in Germany, France and Italy.

\section{Methodology}

The elaboration of differences between France, Germany and Italy at the national level (chapter 4 ) is based on a literature review. The local development strategies of the different LEADER regions provide information on specific challenges in the examined rural areas.

The investigation of RDP implementation processes (chapter 5) comprises the analysis of programme and related guidance documents compiled by the managing authorities. In addition, we used basic financial data from the monitoring and implementation reports of the funding period 2007-2013.

To check the implementation of LEADER at the local level and especially to examine the influences of the factors analysed in chapter 4 and 5 , we conducted ten case studies in nine European regions (Nuts 2): Aquitaine, Bretagne, Rhône-Alpes and Champagne-Ardennes in France, Hesse, Mecklenburg-Vorpommern and North Rhine-Westphalia in Germany and Veneto and Emilia-Romagna in Italy (see Table 1).

The regions were selected based on four main criteria: national institutional organisation, spatial and regional socio-economic characteristics, regional orientations for rural development and local body acting as LAG. The selection of case studies was carried out as presented in figure 3.

In total, we conducted around ten face-to-face qualitative interviews (using interview guidelines) in each single-case study. We interviewed the LAG managers of each LEADER region, LAG members (public as well as private actors) and project initiators. To enable a description of the LEADER processes in the case studies, the LAG composition, the local development strategies of different funding periods and funding data on project implementation in 2007-13 were examined. 
Fig 3. Criteria to choose the LAG case study. Source: own illustration

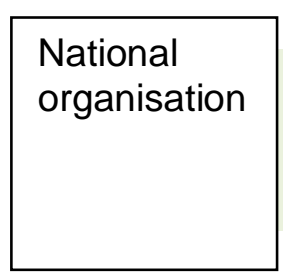

National/
regional
level

\section{Different} types of regions

\section{Territorial} coherence

Experience in LEADER

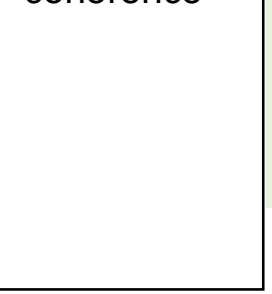

Various state/regional contexts

RDP design

Spatial contexts

Coherence with

administrative borders

Involvement in LEADER
- Centralized state

- Federal state or decentralised state

$\rightarrow$ Regional steering of territorial policies

(European/national/regional)

$\rightarrow$ Various steering depending of policies

- agricultural and forestry competitiveness

- integrated rural development

- public goods and externalities of agriculture

- agricultural equity

- peripheral rural areas

- urbanised rural areas munalités")

- LAG = "Pays"

- $L A G=$ "PNR"

In Germany:
- LAG = part
of a district
- LAG = one
district
- LAG = part
of 2 (or
more)
districts

In Italy:

- $\mathrm{LAG}=$

"Provincia

"

- $\mathrm{LAG}=$ part of 2

"Province "

- LEADER regions with LEADER+ experience 
Tab 1. LAG case studies at a glance.

\begin{tabular}{|l|l|l|l|l|}
\hline \multicolumn{1}{|c|}{ LAG } & Region/Land & \multicolumn{1}{|c|}{ State } & $\begin{array}{c}\text { LEADER } \\
\text { since }\end{array}$ & \multicolumn{1}{c|}{$\begin{array}{c}\text { RDP Focus at } \\
\text { regional/Land-level }\end{array}$} \\
\hline Ouest Cornouaille & Brittany & France & LEADER II & $\begin{array}{l}\text { Performance of the } \\
\text { agricultural sector and } \\
\text { environment }\end{array}$ \\
\hline $\begin{array}{l}\text { Arcachon Val de } \\
\text { l'Eyre }\end{array}$ & Aquitaine & France & $\begin{array}{l}\text { Only part of } \\
\text { the territory } \\
\text { since } \\
\text { LEADER I }\end{array}$ & $\begin{array}{l}\text { Competitiveness of } \\
\text { agriculture and forest } \\
\text { sectors and challenge for } \\
\text { mountain farming }\end{array}$ \\
\hline Monts d'Ardèche & Rhone-Alpes & France & LEADER II & $\begin{array}{l}\text { Local food chains and agri- } \\
\text { environment }\end{array}$ \\
\hline Pays de Langres & $\begin{array}{l}\text { Champagne- } \\
\text { Ardennes }\end{array}$ & France & LEADER II & $\begin{array}{l}\text { Local Infrastructures and } \\
\text { cultural heritage }\end{array}$ \\
\hline Kellerwald-Edersee & Hesse & Germany & LEADER I & Assistance for farmers \\
\hline Stettiner Haff & $\begin{array}{l}\text { Mecklenburg- } \\
\text { Vorpommern }\end{array}$ & Germany & LEADER II & Rural development \\
\hline $\begin{array}{l}\text { Südliches } \\
\text { Paderborner Land }\end{array}$ & $\begin{array}{l}\text { North Rhine- } \\
\text { Westphalia }\end{array}$ & Germany & LEADER + & Agri-environment \\
\hline Venezia orientale & Veneto & Italy & LEADER II & $\begin{array}{l}\text { Rompetitiveness of } \\
\text { protection of the } \\
\text { environment and landscape }\end{array}$ \\
\hline Delta 2000 & $\begin{array}{l}\text { Emilia- } \\
\text { Romagna }\end{array}$ & Italy & LEADER II & $\begin{array}{l}\text { Quality of local products and } \\
\text { environmental issues }\end{array}$ \\
\hline Antico Frignano & Emilia- & Italy & LEADER II & $\begin{array}{l}\text { Quality of local products and } \\
\text { environmental issues }\end{array}$ \\
\hline
\end{tabular}

\section{Framework conditions and administrative systems on the national level}

\subsection{Challenges in rural regions (in case study areas)}

It could appear quite ambitious (and rather false) to present in general the main challenges facing rural regions in Italy, Germany and France, as each region and even local area has its own specificities. Our objective is not to detail all these challenges. Nevertheless, the research report of our project (Berriet-Solliec et al. 2018) presents rough components of each country to keep in mind the influence of historical and institutional patterns to understand development in the case studies. For this article, we just give a short introduction about the different RDP-areas:

\section{French case studies:}

- Brittany is an agricultural region with a powerful agro-food sector based on intensive production. There are important sectoral challenges to face sustainable development issues (water quality, animal welfare, extensification ...). Residential activities are important because of the settlement of new populations and tourism.

- Rhône-Alpes ${ }^{11}$ is an area combining an extensive urban network and mountain areas with many national and regional parks, a region with population growth and strong economic dynamics in the high tech industry, tourism, agriculture and food processing, geared towards quality products.

\footnotetext{
11 We are referring here to the ancient regions. Indeed, the perimeter of the regions changed on 1 January 2016 , grouping the 22 former regions into 13 large regions.
} 
- Champagne-Ardennes is a rural area with a low population density (half of the national average) with remote areas that are losing residents. Agriculture and forestry represent a significant share of employment.

- In Aquitaine, the region is quite diverse with a production-focused industrial agriculture and forestry as well as a combination of residential and natural zones in coastal areas or mountains, where agriculture is declining.

\section{German case studies:}

- In Hesse: South-north divide (better in the south) in terms of economic performance, population density and development, small scale agriculture with a high share of part-time farms.

- In Mecklenburg-Vorpommern (part of former German Democratic Republic in Eastern Germany): low population density, population decline, weak economic structure, especially in coastal areas high importance of tourism.

- In North Rhine-Westphalia (NRW): Most populated federal state in Germany, economic problems in formerly industrialised regions like the Ruhr district, rural areas often with less economic problems and a diverse agricultural structure.

Italian case studies: Both regions are well-developed, and are among the richest Italian regions.

- Veneto is undergoing a process of peri-urbanisation, and is considered as a "diffused city", challenged by serious environmental problems, in particular, water quality and land pollution, and by a strong demand for decentralisation of the rural policy's governance coming from territories (OECD, 2009, 123-124).

- Emilia-Romagna is home to a diversified economic base in which agro-food ${ }^{12}$, manufacturing and tourism activities are strongly developed; but it faces a process of counter-urbanisation with problems related to congestion and pollution due to intense commuting and pressure on natural resources.

\subsection{Institutional framework of administrative systems}

To understand the extent to which the administrative framework influences LEADER, we analysed the systems in France, Germany and Italy, which are quite different.

Germany's principle of territorial organisation gives a high importance to subnational decentralised levels and the principle of subsidiarity. Besides the federal structure, Germany is characterised by a strong position of local government and the territory-related form of organisation leading to multi-purpose administrative units (Kuhlmann and Wollmann, 2014). Local self-government and local administration units below the "Länder" - level are the municipalities (Gemeinde) and the districts (Landkreis), together referred to as municipalities (Kommunen). They have a double nature:

- as local self-government with elected councils and directly elected mayors/head of district as head of the administration and

- as part of the administration of the upper levels executing tasks delegated by the upper levels.

In the 1970s, there was a "wave" of territorial reforms in West Germany to create viable administrative units at the local level. This was enforced by law in some Länder like NRW and Hesse with a substantial decrease in the number of municipalities. After reunification, a similar

\footnotetext{
12 Firms and farms are quite small but strongly integrated along supply-chains, with some important agro-food districts. It is the number one region for production of EU brands (14 protected designation of origin, and 11 Guarantee of origin for foods, such as Parmesan cheese, balsamic vinegar of Modena, Parma ham).
} 
process took place in East Germany. As it was to a great extent voluntary, e.g., in MecklenburgVorpommern(MV), the small municipalities persisted, leading to the establishment of supra local intercommunal cooperations for administration.

The process of decentralisation in France and Italy is more recent. Historically, the two countries have a strong centralised system. In the last decades, both countries made substantial administrative reforms to more decentralised structures. As a result, the role of local governments has gradually been strengthened, but there are strong differences between France and Italy.

France has four levels of administrative organisation: the national level (State) and three regional/local levels (Region, "Département" and municipality) without authority of one to another. Thereby French Regions must contend with an increasing transfer of tasks from the State, even if this latter does not share its legislative power. The State has its own administration at the departmental and regional levels. The process of representation of the State at a territorial level is called "déconcentration", as a counterpart to "décentralisation", meaning that all state responsibilities had to be performed locally by the state field services. Decentralized authorities mean local public services under the responsibility of local authorities. Therefore, there are two kinds of public services that have to work together in each Department and Region (local state services and decentralized authorities), and to negotiate together for local funding and projects.

In France, there is a multitude of small municipalities and the many attempts to reduce them have failed. As an alternative strategy, the government tried to stimulate intercommunal cooperation. This led to a big variety of cooperations ("syndicats") with overlapping and doubling of functions. In the 1990s, a new kind of intercommunal cooperation was introduced to reduce the organisational proliferation. Thus, the 36,500 French communes are today all grouped together into 1263 inter-communalities (Doré, 2018).

Since the adoption of the Bassanini laws in the 1990s, Italy has developed into a quasi-federal state with four levels (national state, region, "provincia" and municipality). Italian regions were granted legal responsibility from the state in many areas, and particularly were given legislative power (Rivières, 2004). Italy has fewer municipalities than France but they are still numerous.

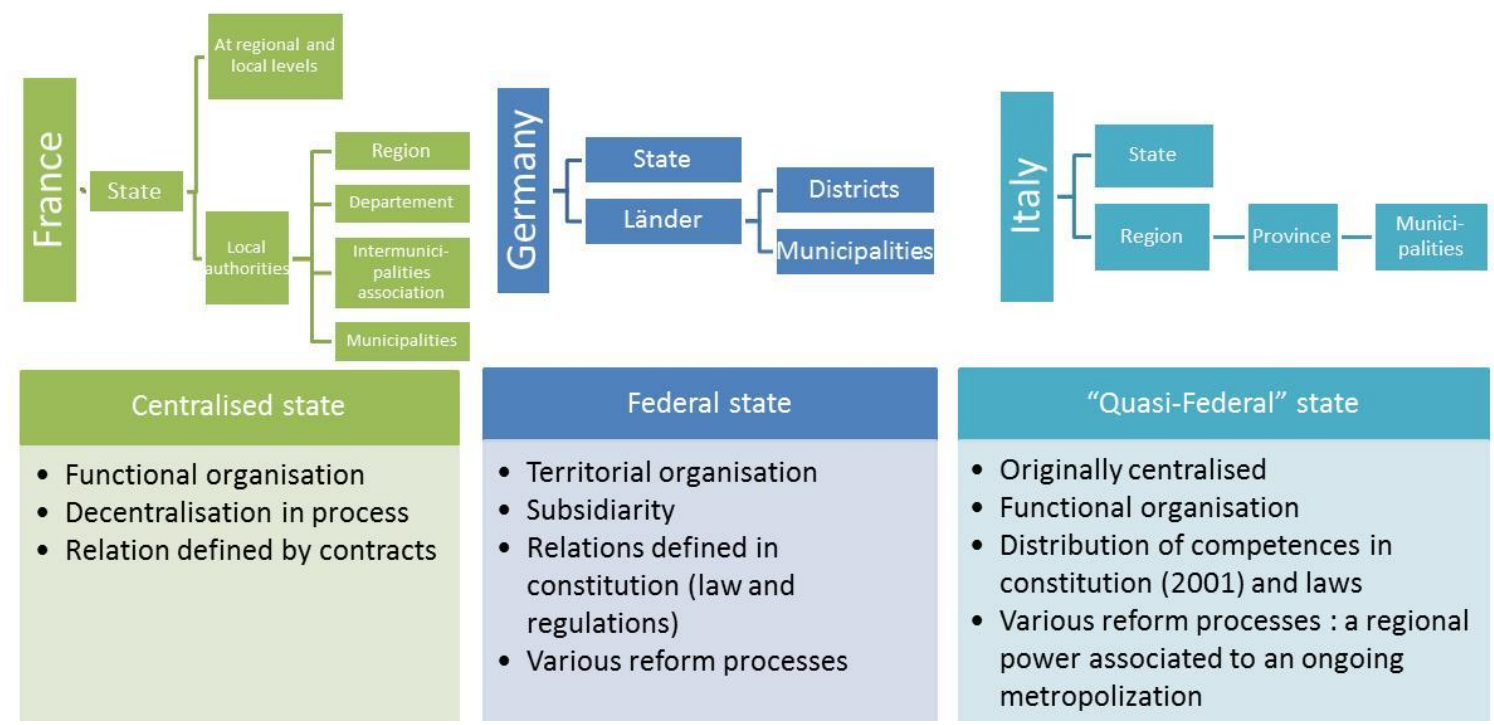

Fig 4. Overview of public administration in France, Germany and Italy ${ }^{13}$. Source: Berriet-Solliec et al., 2016

\footnotetext{
13 As the reform process is quite dynamic in Italy and to a certain extent also in France, this figure reflects the situation as presented in literature by time of elaboration and not by time of publication. See i. a. Kuhlmann \& Wollmann 2019.
} 
The analysis of the administrative organisation in these three countries highlights that in the multilevel governance setting, the state has given up some of its control functions in favour of a coordination role (Mantino et al., 2009) or "gouvernance à distance" (Epstein, 2005).

\section{RDP implementation in the case study regions}

European legislation, more specifically the EAFRD regulation, defines the rules and conditions for the so-called second pillar of the Common Agricultural Policy. Based on the menu of funding measures presented in this regulation, the member states draw their rural development programs (RDPs) at the national level, or in case of federal or quasi federal states, at sub national level. So, member states are supposed to tailor the funding opportunities and conditions to their specific characteristics, e.g., in terms of administrative procedures or needs in rural areas, while it is compulsory for some measures, like LEADER, to be included in RDP. In the following two chapters, we examine the differences of how the frame set by the EU-COM is transferred into rural development policy at first at national level and then zooming into the subnational level.

\subsection{National level}

In France, initially, there was a single National Rural Development Programme (PDRN) for the mainland in the funding periods before 2007. For the 2007-13 period, there was still a national programme but it was composed of two parts. A national part ("Socle national') concerned certain measures of Axes 1 and 2 and corresponded to main national issues (young farmers, compensatory allowance for permanent natural handicaps, some agri-environmental measures and forestry measures). It represented $62 \%$ of EU funds. A regional programme part ( $38 \%$ of EU funds) is elaborated by each Region. The national part is completed by 26 regional documents of rural development (DRDR) elaborated by Regions for all measures from Axes 3/4 (and also some for Axes 1/2 that can be adapted to the specific regional context).
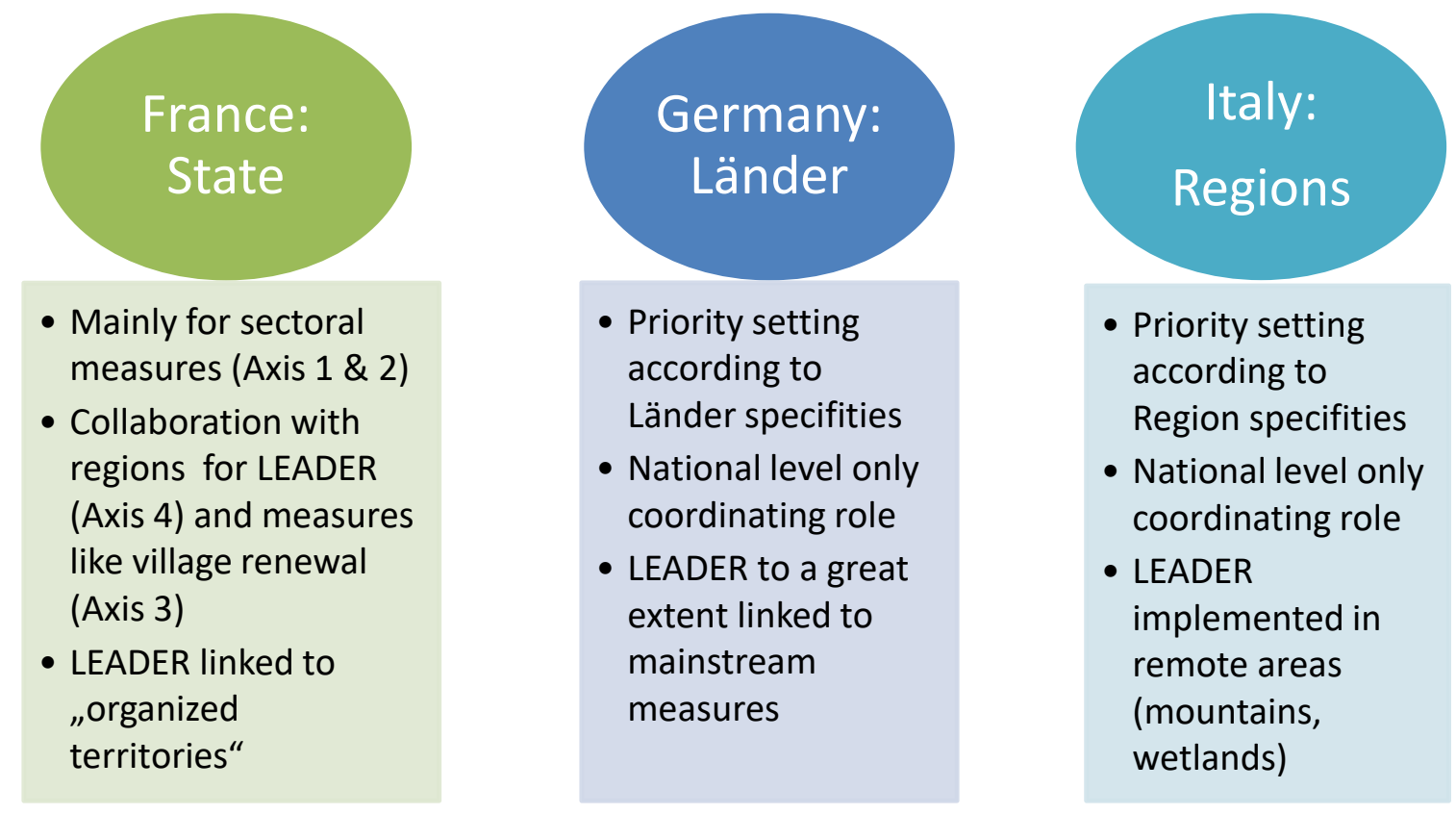

Fig 5. Responsibility for RDP 2007-2013 planning and implementation in France, Germany and Italy. Source: own composition

LEADER was seen as a tool to implement the national policy of "pays" developed in 1999 by the French government. "Pays" are subregional areas regrouping some inter-communalities, based on existing historical, cultural or socio-economic links among the population like economic and public actors. The aim of pays is to define and lead a territorial development 
strategy. In this context, LEADER became a tool of territorial policies of regions and implemented at the level of the pays (75\% of French LEADER LAGs are led by Pays (Final assessment of French RDR, 2017)).

In Germany, the Länder (federal states) have the responsibility for agriculture as well as for regional economic development. Thus, the Länder set up 14 RDPs. The Bund (national state) basically has a coordinating role (and is responsible for agricultural direct payments). The national strategic plan required by the EU for 2007-2013 was elaborated by the national Ministry of Agriculture, summarising the contents of the Länder programmes. It had no strategic relevance.

In Italy, like in Germany, the regions are responsible for the planning and implementation of RDPs, and the State, and its agricultural ministry, has no constitutional legitimacy to take action in regional policy orientations (Cobacho et al., 2011). This led to basic differences in programmes, for example, concerning the criteria for the definition of rural areas, thus generating disparities between regions and potential beneficiaries in earlier funding periods. As for the funding period 2007-13, Member States had to elaborate a national strategic plan, the Agriculture Ministry worked with the Regional State Consultation, called "Conferenza Stato Regioni" to elaborate this plan and to harmonise the implementation of the rural development planning, notably the definition of rural areas.

\subsection{At sub national level (Länder/Regions)}

The differences in the structure of RDPs becomes obvious looking at the financial distribution between Axes in Figure 6 (see also Konečný 2019 for a European overview).

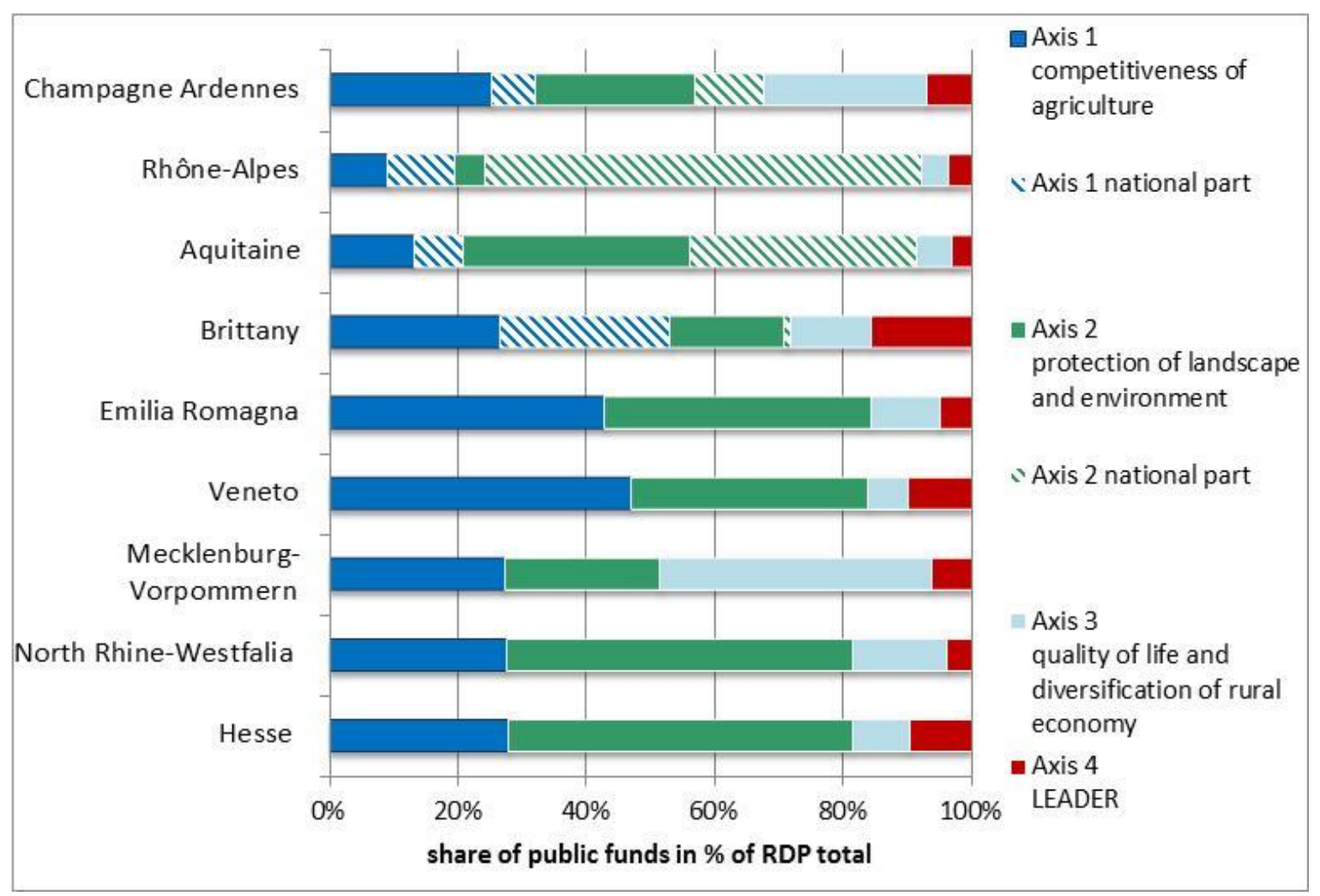

Fig 6. Financial RDP distribution per axis (2007-13). Source: RDPs and annual implementation reports, see http://enrd.ec.europa.eu/en/country.

There is an emphasis on sectoral measures benefiting farmers (Axis 1) in both Italian regions as well as in agricultural French regions, such as Brittany. In the German programmes, in Hesse and NRW, Axis 2 is very important due to the relevance of agri-environmental measures in NRW and the less-favoured areas subsidies in Hesse. In both French regions, Rhône-Alpes and 
Aquitaine with important mountain areas, Axis 2 is very important as well, because of payments for farmers in mountains areas. In Mecklenburg-Vorpommern, the programme reflects the need to develop the rural infrastructure and economy, allocating the biggest share to Axis 3 . There are also clear differences in the weight the regions/Länder give to the LEADER axis (with $21 \%$ of public funds in Brittany and only about $5 \%$ in North Rhine-Westphalia and Emilia-Romagna).

Another distinguishing feature can be the kind of projects that are eligible for LEADER:

- In France, Regions are free to define relevant territories and strategic priorities for LEADER, mobilising all measures included in the respective regional programmes ${ }^{14}$. Under these conditions, we observed that LEADER is more oriented to measures of Axis 3 and measures of Axes 1 and 2 are used only rarely and less intensively.

- In Germany, this varies between the Länder: while in Hesse only the standard Axis 3 measures are possible, and in NRW all projects have to be so-called innovative measures, in Mecklenburg-Vorpommern all measures from Axes 1,2 and 3 have been fundable through LEADER. Because this restriction leads to too narrow conditions, MecklenburgVorpommern already widened the possibilities during the funding period with an option called "LEADERalternative", which made it easier to fund projects, which do not fit in the standard measure funding conditions.

- In Italy, the Regions offer different measures to LEADER. Some use only the Axis 3, others combine Axis 3, with Axes 2 or 1 and others use all three axes (Di Rienzo and al., 2012, 18). Emilia-Romagna and Veneto have chosen the latter.

Regarding the history of LEADER implementation in France, for a long time there have been tensions between the will of the state to maintain equity/ national consistency and regional claims to control their own development path. These tensions are illustrated by Méasson (2007) who speaks about the "recentralisation" of LEADER+ compared with LEADER II. Nevertheless, we can underline some specificities:

- In Brittany, even if the regional programme is focused on the agricultural competiveness, there has been a long tradition of local development based on Pays since the 1960s. The Region even wanted to recognise all the 22 Pays as LEADER areas. Regional services of the state did not accept this non-selective strategy and only 15 LAGs were selected without the support of Regional council.

- In Aquitaine, there has been a good cooperation between the state and regional council since LEADER I. The Aquitaine Region has a specific urban and rural policy (Pays et Quartiers d'Aquitaine) that is closely linked to LEADER programmes and is, as such, a major source of co-funding of LEADER.

- Rhône-Alpes is an economically powerful region that has for a long time recognised Natural Parks and Pays. LEADER is used as a political lever to implement and promote the region's own territorial development strategy.

- Champagne-Ardennes failed to get LEADER I funding. That is why local actors, convinced that LEADER could be a great opportunity to help the Region to fight unemployment and regional social difficulties, received a specific training to design LEADER. In this context, the Haute-Marne Department (the poorest department in Champagne-Ardennes) was successful in obtaining LEADER II support for its LAG designed by civil society and local economic and public actors.

Regarding the history of LEADER implementation in Germany, there are some differences in the three Länder:

\footnotetext{
14 In accordance with RDR agreement, project leader can also mobilize measures available in national program and not selected in a regional program.
} 
- In Hesse: The promotion of endogenous rural development was already firmly rooted in Hessian rural development policy before LEADER I and an association for autonomous regional development was already set up in 1984 with the first rural regional programme. This led to a certain openness to decentralised and regional approaches among political authorities when the LEADER I programme was introduced (Thelen, 1999). In LEADER I, two LAGs evolved, by the end of LEADER II six LEADER-LAGs existed. In LEADER+ the number of LAGs increased to eight and in 2007-2013 to 20 LAGs (together with a similar type of region already established in the LEADER-II-phase covering nearly all rural areas in Hesse).

- In North Rhine-Westphalia: In former funding periods, NRW was one of the federal states not as open to LEADER as others. The first LEADER LAGs were only established with LEADER+. The relevance of LEADER has quite increased through mainstreaming as the number of LAGs quadrupled from three to twelve in 2007-13.

- Mecklenburg-Vorpommern (former eastern Germany) did not participate in LEADER I, but then 12 areas were approved for LEADER II. The regions were equal to districts and all districts in MV participated. In LEADER+, the shape of the LAG regions was reviewed. While again 12 LAGs were selected, the delimitations changed and differed from district borders in most cases. For 2007-2013, again the whole surface of rural areas is covered with LAGs (13 regions again mainly oriented on district borders).

Regarding the history of LEADER implementation in Italy, we can highlight some differences between Emilia-Romagna and Veneto:

- In Veneto, even if the 2007-13 RDP was focused on competitiveness of agriculture which was the same in 2000-2006 for the place and importance of LEADER+, there is a long rural tradition of local development. Since LEADER+, the LEADER programme in Veneto is focused on measures including improving the quality of life.

- Emilia-Romagna, one of the richest regions in Italy, is considered by the EU Commission as "textbook case study" for LEADER, with regards to innovations and involvement of private actors (Fargion et al., 2006). It was recognised as an "excellence-region-system", pursuing in its policies both objectives of development and social cohesion. For 2007-13, the LAGs Antico-Frignano and Delta 2000 illustrate the two dimensions of the regional LEADER strategy: the first one with a strong agricultural part, represented by agricultural cooperatives in LEADER design and management, and the second one with a strong part dedicated to environmental issues, the Delta 2000 region is classified as a Natura 2000 and UNESCO area.

\section{Comparative analysis: LEADER implementation at a local level}

\subsection{Consequences of the upper levels and the administrative environment for LEADER implementation at the local level}

The findings from Chapters 4 and 5 highlight the diversity of administrative structures and the role of different levels. What are the consequences on the implementation of LEADER?

Regarding the influences of the institutional environment, it is important to keep in mind that communes are multipurpose administrations in Germany executing a vast range of tasks, communes in France and Italy are overall self-governmental units and other administrative tasks are organised sectorally. With regards to LEADER, communes in Germany might have more resources and technical capacities for project planning and implementation. In France, intermunicipality associations might give more power to support their interests and allow pooled financial and human resources.

In France, territorial organisations relevant for LEADER are called "Territoires organisés". These are not new levels, but other types of defined territories between municipalities without regard to existing administrative borders. Most common territorial organisations are "Pays" or Regional natural Parks (PNR), which are not part of a local public government, but cooperative 
organizations between several intermunicipal associations. LAG members from the public sector are elected representatives of the municipalities, inter-municipality associations, other public structures as Pays or natural parks, or public professional organisation such as chambers of agriculture, commerce or crafts.

In Germany, as LEADER territories were relatively free in deciding on their delimitations, they are not always coherent with administrative or other existing units. Relevant units are municipalities, districts, natural parks or former districts. LAG members from the public sector are usually local mayors or from the administration of municipalities and districts, but not from higher levels. In some Länder, it is obligatory that representatives of the government authorities, who are responsible for the eligibility check, are advisory members in every LAG.

In Italy, LEADER territories are defined according to specific national criteria. In each Region the LAGs have a legal status that gives them independence. However, each LAG has to respect regional RDP priorities. In Veneto, there is a traditional rural governance model and LAGs in LEADER focus on matters of Axis 3. Main actors vary according to the local development strategy. In Emilia-Romagna, in the LAG Antico-Frignano, the priority is the development of local products supported by Axis 1, which is also illustrated by the bigger share of Axis 1 measures in the LEADER budget (Fig. 7). In that case, the main actors here are agricultural cooperatives and private agri-food enterprises. In contrast, in LAG Delta 2000, with a local development strategy based on the enhancement of local products and wetlands, agricultural trade unions and tourism actors are well represented. In both cases, the LAG members from the public sector are the municipalities, and when present, actors from parks and "Unione di communi" (association of municipalities).

As Fig. 7 shows, the financial importance of LEADER varies significantly between the regions/Länder concerned and there are strong differences in the budget of public funds available for each LAG. The highest budget is available to LAGs in the economically well-off Italian regions and the trailing east-German Land, Mecklenburg-Vorpommern.

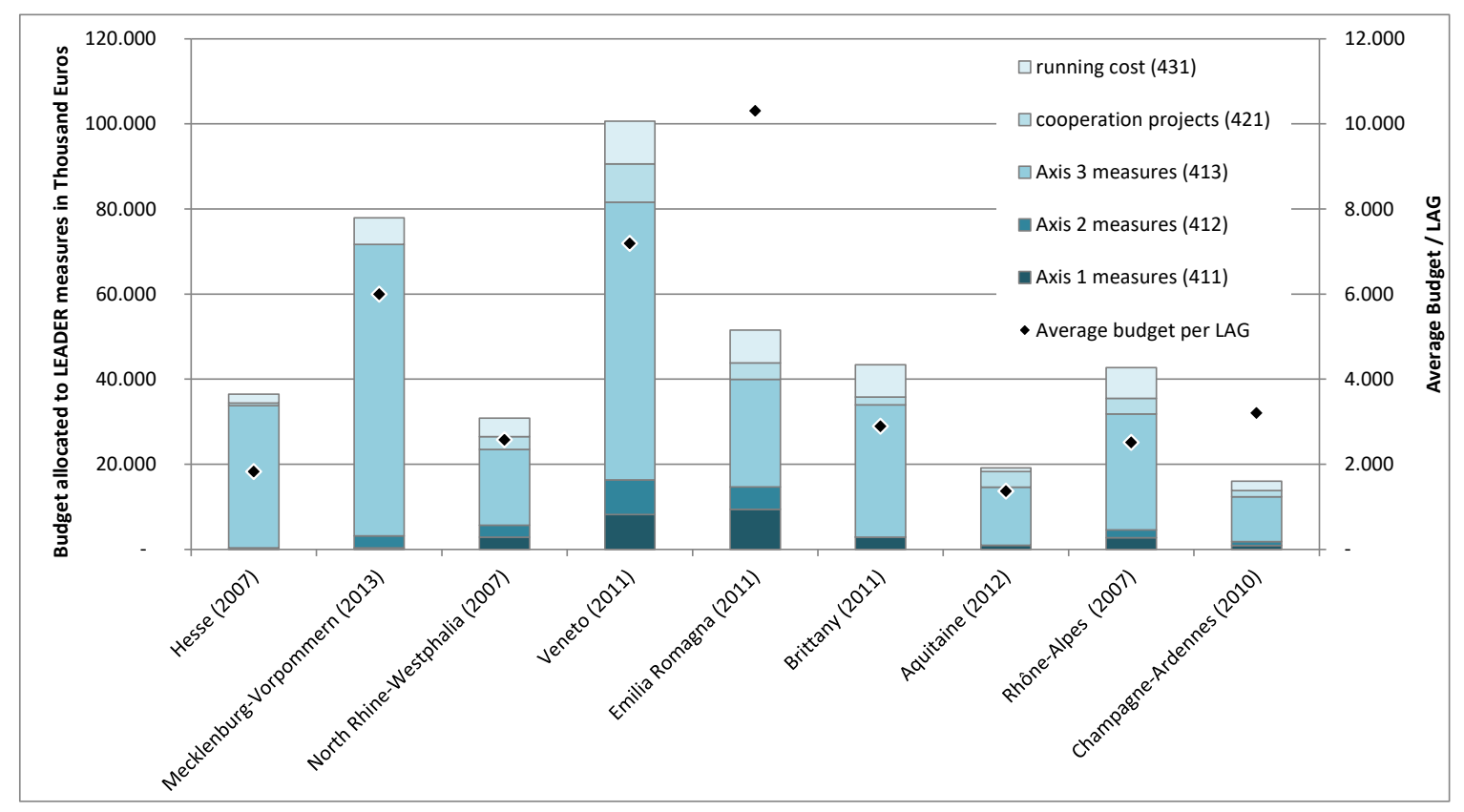

Fig 7. Budget (public funds) allocated to LEADER measures by Region/Land (2007-2013). Source: RDPs and annual implementation reports, see http://enrd.ec.europa.eu/en/country.

Regarding the type of beneficiaries, there are differences between the three countries (Fig. 8). The high share of public sector as project operators in Germany follows higher capacities and the strong role of municipalities in LEADER processes, whereas the high share of private sector individuals in Italy shows that economic actors, agricultural cooperatives and trade-unions, agrifood enterprises or tourism enterprises play an important role. 


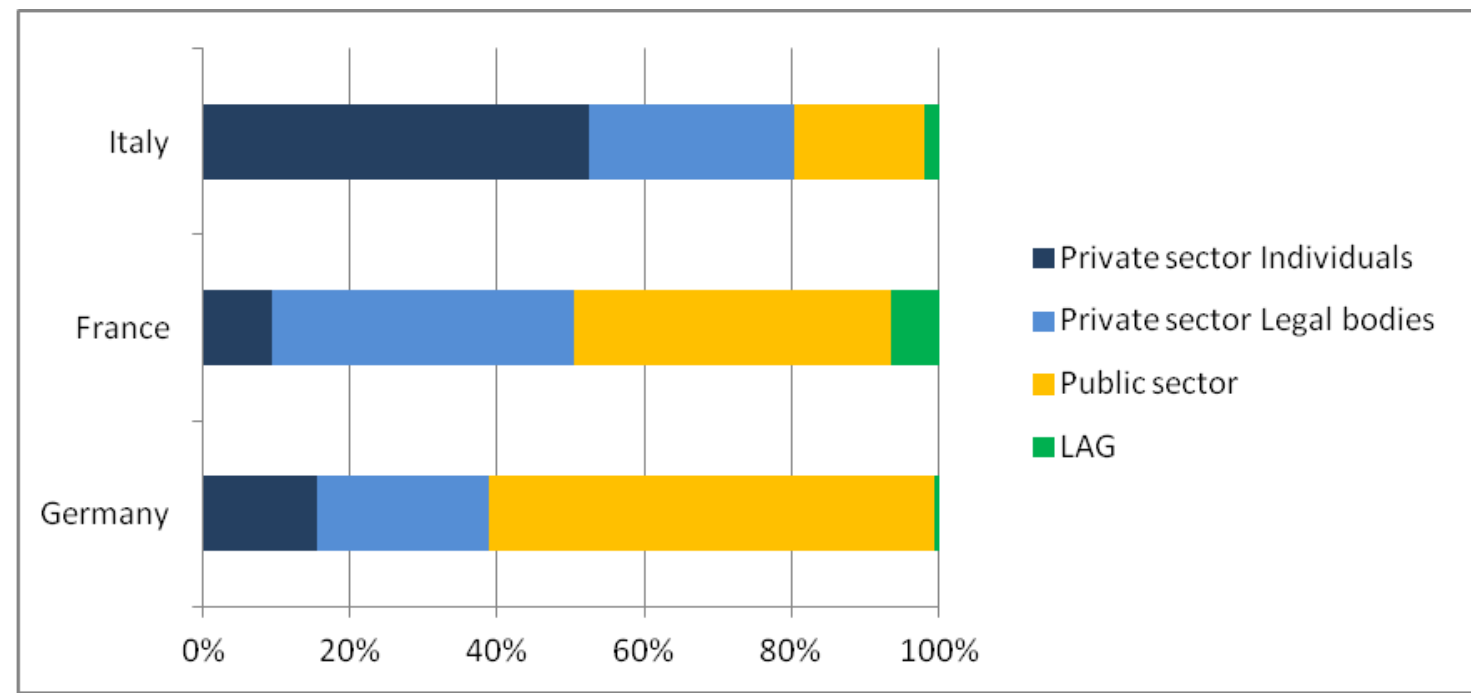

Fig 8. Public funds spent for LEADER projects by type of beneficiary. Source: Output Indicators: realised 2007-2012 (http://enrd.ec.europa.eu/sites/enrd/)

\subsection{Insights from case studies}

The comparative analysis of LEADER implementation at the local level in our case studies leads us to highlight the following results:

- Impacts from administrative framework on LAG composition: especially if change of funding conditions is perceived as change for the worse, some groups become dissatisfied and discontinue their engagement (Examples: stakeholders from forestry in the Paderborner Land left the LEADER-process as a result of changes in funding rules from LEADER+ to mainstreamed LEADER 2007-2013, but came back for 2014+ because they expect improvements in funding conditions). New actors have been integrated 2014+ in the Stettiner Haff because of demands from the Land to include topics like energy/climate protection. In France, the negotiating logic between the state and the regions leads to very different methods of implementing LEADER between regions. For example, in Brittany, the Region disagreed with the state-dominated 20072013 LEADER selection process. Since in 2014-20 the Region became the managing authority, all "Pays" are now involved in LEADER.

- Changes of LAG delimitations in connection with administrative borders: To meet the needs of local stakeholders, it is important that the size of the region is not too large (example: In the funding period 2007-2013 Stettiner Haff switched back to the smaller area it already covered in LEADER II. This change clearly supported the need of local stakeholders to act in the region they really know well). Our study showed that the delimitations of LEADER areas often do not follow rigid administrative borders, but are delimitations based on a variety of criteria consistent with the development strategy. Comparison between the three countries shows different conceptions of what is the relevant territory to lead local development. In France, the old experiences of local development since the 1980s have also been drawn in in response to centralised planning policies. It led to the establishment and recognition of territories aimed at fostering the emergence of territorial development strategies by federating municipalities and inter-communalities. These territories, governed by local actors especially organised in development councils and not linked to local self-government, have established themselves as the legitimate perimeters for the implementation of LEADER. At the same time, by providing financial and engineering resources, LEADER consolidated this territorial organisation, which is quite unique in Europe. In Germany and Italy, the constitution of LAG territories does not much follow some prevailing patterns. LAG 
delimitation is predominantly based on the specific context which means that each LEADER territory has its singular story resulting from history, socioeconomic and natural conditions and interaction between the stakeholders present on the ground, which can go as in Italy until a strong capacity to engage private actors.

- Impacts of the LAG status on actors' commitment and on the private actors' participation in LEADER: comparative analysis allowed two types of actors commitment in LEADER programmes to be distinguished. In France and in Germany, members of LAGs often have the status of representatives of a category or group of economic, professional, civil society or public actors. Their volunteer commitment is mainly selfless and motivated by the general interest (or the interest of their groups like environmental protection, but then not dominantly motivated by seeking for money for their own organisation/projects). The strategic dimension of the LEADER project and its relevance to the challenges of the territory are central to the motivations of the members involved in the governance of LEADER. The statutes of LAGs are public.

In Italy, the legal governance structure of the LAG is a private organisation in two case studies out of three. It is materialised by a financial investment of the members, which implies an expectation of results in return. This "return on investment" is not strictly motivated by the assurance of being able to directly benefit from LEADER funding, but results in credible, visible social and economic expectations of benefits. The participation of private actors evolves quite differently in our case studies according to the LAG status and the independence from administrative structures. For example, in Delta 2000 (I) or Ardèche $(F)$, the LAG is closely linked to a natural park. In Ardèche, the LEADER strategy is quite similar to the park's strategy and private actors have difficulties becoming involved in the LAG. In contrast, in Delta 2000, created to give a local development strategy to the natural regional park, private actors are numerous and include environmental educational actors, sustainable tourism enterprises, local food enterprises. In this case, LEADER contributes to reinforce the partnerships between public and private actors and the cohesion of local actors.

- Impacts of territorial engineering on local actors involved in LEADER: Engineering provided by institutional structures (Land, State, Region, territorial development institutions ...) could have an impact on local actors in terms of social learning and empowerment. For example, in the remote area "pays de Langres", with LEADER II, local actors were trained to improve their practices in terms of project management and information dissemination. LEADER created an area of empowerment of local issues and brought a relevant lever for a local development that includes weakest actors in a common project and an active citizenship.

\subsection{Discussion of results}

First assumptions are that especially in France, sometimes in Germany as well, the importance of territorial control games by national authorities tends to reproduce a territorial order where public policy takes shape in confined spaces defined as priori. In these situations, the defence of the institutionalised territory (Pays, Parks, regional project territory, districts ...) becomes the dominant logic of action and may inhibit local initiatives. In Italy, the same situation could be observed, but is played by regional authorities. These observations are in line with results from other countries (Poland: Falkowski 2013, Hungary: Fekete 2014, and Spain: Navarro et al. 2015).

Nevertheless, in the nine regions under study and in remote areas in particular, LEADER, as a rural development tool, participates in reinforcing local empowerment thanks to territorial engineering. Other research underpins that territorial engineering is the most important distinctive factor for the differences in the level of the capacity of innovation between territorial governments (Chevalier and Vollet 2018). This functioning is also related to country-specific experiences with the LEADER method and possibilities to allocate social capital in the region. Differences between old and new Member States are also discussed by Konečný (2019). 
Our results point to the differences in the three countries. Beyond these differences, the question about a suitable RDP-programme design is relevant for the next programming for all the Member States of the EU. LEADER receives special attention from the Member States and the Commission in European policies. LEADER has been renewed in each multi-annual period and currently counts $2664^{15}$ LAG and covers $61.9 \%{ }^{16}$ of the European population. In the 2014-2020 programming period, the LEADER approach was expanded to other European Structural and Investment Funds through CLLD. The programming for post-2020 seems to follow this concept with options for a multi-fund approach.

Different researchers comment on and interpret these evolutions in very different ways. For example, Navarro et al. 2015 declare LEADER to be "a victim of its own success." Dax et al. 2015 acknowledge the efforts for improvement in the current funding period after a degradation through mainstreaming, and Konečný (2019) explains differences with implementation experiences. Laidin (2019) highlights the weakness of LEADER's financial budget, but also its sustainability.

Overall, we can observe the attempt to spread LEADER principles in the implementation of European policies level while at the same time this process is perceived as a dilution of these LEADER principles by local actors, who have experienced successive generations of LEADER programmes.

\section{Conclusion}

Our findings highlight the diversity of LEADER implementations in the three countries and the influence of institutional factors. Each LEADER implementation system reflects specific socio-economic structures and different conceptions of local and/or rural development. The design of the RDPs influences the extent to which local actors from different spheres get involved in local development via LEADER. This may occur by means of funding conditions or demands on institutional settings at the local level. Further analysis of our case studies is required to trace the path between these national differences induced by the framework and the effect LEADER has on local governance and development.

Although it is challenging to prove the impact for rural development, LEADER is an approach, which works in very different administrative environments to improve rural cooperation. Thus, obviously LEADER is perceived as a positive brand for a participative way of promoting rural development. This will lead to a resumption in the next funding period. To optimise the implementation, our research results highlight the importance of taking into account the specific conditions in different countries. Some key elements required to maintain the "LEADER spirit", such as a certain degree of openness for delimitation rules and requirements for participation are crucial for all Member States. Other conditions should be adapted to the characteristics of the individual Member States. The effectiveness of LEADER depends on the potential to bridge a gap. For example, although in Germany, there is a long tradition of self-administration on the local level (municipalities), there is often a gap in the intersectoral cooperation beyond administrative borders. In this case, the involvement of different actors at the LAG level can foster improvements. In France, LEADER could give support to the process of decentralisation. In Italy, there is often a gap in the sense of a "lack of trust in collective action". Here, the additional capacity for territorial engineering helps to reinforce local empowerment.

Thus, if a crucial conclusion of this article is that different boundary conditions together with local administrative environments affect the LEADER implementation on local level, the recommendation is that this aspect should be considered in the design of rural development programmes. Although this is quite different between regions and countries, a common task for all of the three examined countries and certainly for all Member States is to avoid "control games" of local/regional public sector actors.

\footnotetext{
${ }^{15} \mathrm{https}$ ///agridata.ec.europa.eu/extensions/Dashboardlndicators/DataExplorer.html

16 https://cohesiondata.ec.europa.eu/funds/eafrd\# "Achievements"
} 
[1] Bache, I. \& Flinders, M. (2004): Multi-level Governance. Oxford: Oxford University Press

[2] Berriet-Solliec, M. \& Trouvé, A. (2010): Regionalization in European Agricultural Policy: Institutional Actualities, Issues and prospects. Regional Studies 44(8), 1005-1017. DOI: 10.1080/00343400903365177.

[3] Berriet-Solliec, M., Lépicier, D. \& Vollet, D. (2017). Analyse croisée de la valeur ajoutée et des coûts de transaction: quel intérêt pour les politiques territoriales? Application au programme Leader 2007-2013 en Auvergne et Bourgogne. Norois 4(241), 15-32.

[4] Berriet-Solliec, M., Laidin, C., Lépicier, D., Pham, H. V., Pollermann, K., Raue, P. \& Schnaut, G. (2016). The LEADER process as a European policy for local development: A comparison of the implementation in three European Member States. [Working Paper CESAER N ${ }^{\circ}$ 2016/1].

[5] Berriet-Solliec, M., Laidin, C., Lepicier, D, Pham, H., Pollermann, K., Raue, P. \& Schnaut, G. (2018). Governance of policy at a local level LEADER programs analysis: TRUSTEE (Towards Rural Synergies and Trade-offs between Economic Development and Ecosystem Services) [Deliverable 3.3]. Braunschweig; Dijon; Rennes.

[6] Bosworth, G., Annibal, I., Carroll, T., Price, L., Sellick, J. \& Shepherd, J. (2016). Empowering Local Action through Neo-Endogenous Development; The Case of LEADER in England. Sociologia Ruralis 56(3), 427-449. DOI: 10.1111/soru.12089.

[7] Cotta, M. \& Verzichelli, L. (2011): II sistema politico italiano. Bologna: Il Mulino.

[8] Chevalier, P. \& Vollet, D. (2019) LEADER 2007-2013: An innovation dependent on local and national institutional arrangements? Some European illustrations. Regional Science Policy \& Practice: 1-16.

[9] Chevalier, P, Dedeire, M. (2014). Application du programme LEADER selon les principes de base du développement rural. Economie rurale, $\mathrm{N}^{\circ} 342$, pp. 9-26.

[10] Chevalier, P., Mačiulyté, J., Razafimahefa, L. \& Dedeire, M. (2017). The Leader Programme as a Model of Institutional Transfer: Learning from Its Local Implementation in France and Lithuania. European Countryside 9(2), 317-341. DOI: 10.1515/euco-20170020.

[11] Cejudo, E. \& Navarro, F., eds. (2020). Neoendogenous Development in European Rural Areas: Results and Lessons. Cham: Springer.

[12] Dax, T., Strahl, W., Kirwan, J. \& Maye, D. (2016). The Leader programme 2007-2013: Enabling or disabling social innovation and neo-endogenous development? Insights from Austria and Ireland. European Urban and Regional Studies 23(1), 56-68. DOI: $10.1177 / 0969776413490425$.

[13] Doré, G. (2018). Le bouleversement territorial en France: analyse et enjeux. Population Avenir 736, 4-7. DOI: 10.3917/popav.736.0004.

[14] Epstein, R. (2005). Gouverner à distance: quand l'État se retire des territoires, Esprit, 319, 96-111.

[15] Fałkowski, J. (2013). Political accountability and governance in rural areas: Some evidence from the Pilot Programme LEADER+ in Poland. Journal of Rural Studies 32, 70-79. DOI: 10.1016/j.jrurstud.2013.04.008.

[16] Fargion, V., Morlino, L., Profeti, S. \& Roux, C. (2006). Européanisation et représentation territoriales en Italie. Pôle Sud 24, 99-120. DOI: 10.3917/psud.024.0099.

[17] Grieve, J., Lukesch, R., Weinspach, U., Fernandes, P., Brakalova, M., Cristiano, S., Geissendorfer, M., Nemes, G., O'Gready, S., Sepùlveda, R., Pfefferkorn, W., Pollermann, K., Pylkkänen, P., Ricci, C. \& Slee, B. (2011). Capturing impacts of LEADER and of 
measures to improve Quality of Life in rural areas. European Association of Agricultural Economists 122nd Seminar, February 17-18, 2011, Ancona, Italy. Wageningen: European Association of Agricultural Economists.

[18] Konečný, O. (2019). The LEADER approach across the European Union: One method of rural development, many forms of implementation. European Countryside 11(1), 1-16. DOI: 10.2478/euco-2019-0001.

[19] Kuhlmann, S. (2014). Multi-level Governance in Kontinentaleuropa: Mehrebenenverflechtung und institutionelle Reformfähigkeit im deutsch-französischen Vergleich, Zeitschrift für Vergleichende Politikwissenschaft 8(1), 193-210. DOI: 10.1007/s12286-0140198-5.

[20] Kuhlmann, S, \& Wollmann, H. (2014). Introduction to Comparative Public Administration: Administrative Systems and Reforms in Europe. Cheltenham: Edward Elgar.

[21] Kuhlmann, S. \& Wollmann, H. (2019). Introduction to comparative public administration. Administrative systems and reforms in Europe. $2^{\text {nd }}$ ed. Cheltenham: Edward Elgar.

[22] Lacquement, G. \& Raynal, J. C. (2013). Actors and resources of local development in eastern Germany: the rural territory shown through the European programme LEADER projects. Annales de Géographie 692, 393-421. DOI: 10.3917/ag.692.0393.

[23] Laidin, C. (2019). Quand l'Europe promeut le rural: le programme LEADER en France et en Italie [PhD theses]. Rennes: Université Rennes 1.

[24] Laidin, C. \& Berriet-Solliec, M. (2016). LEADER pour les campagnes littorales: une analyse critique. Economie Rurale 351, 25-47. DOI: 10.4000/economierurale.4800.

[25] Mantino, F., Bolli, M., Fagiani, P. \& Tarangioli, S. (2009). Report on policy delivery systems and their relations with types of governance models: assessing the impact of rural development policies (incl. LEADER). Roma: INEA.

[26] Méasson, L. (2007). L'efficacité territoriale et l'évaluation. Penser le déploiement spatial du politique grâce au programme européen LEADER [PhD theses]. Grenoble: Université Grenoble I - Jouseph Fourier.

[27] Meier, K. J., O'Toole Jr., L. J. \& Nicholson-Crotty, S. (2004). Multilevel governance and organisational performance: Investigating the political-bureaucratic labyrinth. Journal of Policy Analysis and Management 23(1), 31-47. DOI: 10.1002/pam.10177.

[28] Navarro, F. A., Woods, M. \&, Cejudo, E. (2015). The LEADER Initiative has been a Victim of Its Own Success. The Decline of the Bottom-Up Approach in Rural Development Programmes. The Cases of Wales and Andalusia. Sociologia Ruralis 56(2), 270-288. DOI: $10.1111 /$ soru.12079.

[29] Navarro, F., Labianca, M., Cejudo, E., de Rubertis, S., Salento, A., Maroto, J. C. \& Belliggiano, A. (2018). Interpretations of Innovation in Rural Development. The Cases of Leader Projects in Lecce (Italy) and Granada (Spain) in 2007-2013 Period. European Countryside 10(1), 107-126. DOI: 10.2478/euco-2018-0007.

[30] Oedl-Wieser, T., Strahl, W. \& Dax, T. (2010). The LEADER programme 2007-2013: refocusing towards agriculture-oriented activities as a consequence of 'mainstreaming' innovative rural action in Austria [paper presented in the $118^{\text {th }}$ EAAE Seminar "Rural development: governance, policy design and delivery", Ljubljana (Slovenia)]. DOI: 10.22004/ag.econ.94622.

[31] Perraud, D. (2001). Les politiques agricoles et rurales dans les régions: une nouvelle organisation des pouvoirs publics en Europe? Economie Rurale 261, 7-22. DOI: 10.3406/ecoru.2001.5215. 
[32] Pollermann, K. (2014). Processes of cooperation in rural areas: obstacles, driving forces and options for encouragement. In Kasabov, E., ed., Cooperation in rural, peripheral areas of Europe: challenges and solutions (pp. 210-227). Basingstoke: Palgrave Macmillan.

[33] Pollermann, K. (2016). LEADER 5.0 - Die Versionsgeschichte des LEADER-Ansatzes und Anforderungen an die Evaluierung für eine evidenzbasierte Politikberatung. Dortmunder Beiträge zur Raumplanung 147, 123-138.

[34] Pollermann, K. \& Raue, P. (2020). Relations between local institutional settings and governance arrangements in LEADER: looking for differences from different national and federal state related contexts. Berlin: LIT.

[35] Pollermann, K., Raue, P. \& Schnaut, G. (2013). Rural Development experiences in Germany: opportunities and obstacles in fostering smart places through LEADER. Studies in Agricultural Economics 115, 111-117. DOI: 10.7896/j.1228.

[36] Pollermann, K., Raue, P. \& Schnaut, G. (2014a). Multi-level governance in rural development: analysing experiences from LEADER for a Community-Led Local Development [CLLD]. In ERSA 2014 - 54th Congress of the European Regional Science Association, St. Petersburg, 2014. Conference Papers. Louvain-la-Neuve: ERSA.

[37] Pollermann, K., Raue, P. \& Schnaut, G. (2014b). Opportunities for a participative approach in rural development: Findings from LEADER in Mecklenburg-Vorpommern and the requirements for Community Led Local Development. Landbauforschung Appl Agric Forestry Res 64(3/4), 127-138. DOI: 10.3220/LBF_2014_127-138.

[38] Pollitt, C. \& Bouckaert, G. (2011). Public Management Reform: A Compative Analysis New Public management, Governance and the Neo-Weberian State. Oxford University Press.

[39] Rivière, D. (2004). L'Italie: des régions à l'Europe. Paris: Armand Colin.

[40] Rizzo, F. (2013). LEADER policy practices and landscapes in the light of the agencystructure debate: evidence from LEADER local action groups in Italy and in Finland. European Countryside, 5(3), 232-250. DOI: 10.2478/euco-2013-0015.

[41] Teilmann, K. \& Thuesen, A. (2014). Important Types of LAG-Municipality Interaction When Collaborating on Rural Development Lessons from Danish LEADER LAGs. International Journal of Rural Management, 10(1), 21-45. DOI: 10.1177/0973005214526501.

[42] Thoenig, J.-C. (2005). Territorial administration and political control: decentralization in France. Public administration 83(3), 685-708. DOI: 10.1111/j.0033-3298.2005.00470.x.

[43] Thuesen, A. A., Nielsen, N. C. (2014). A Territorial Perspective on EU's Leader Approach In Denmark: The Added Value Of Community-Led Local Development Of Rural And Coastal Areas In A Multi-Level Governance Settings. European Countryside 6(4), 307-326. DOI: 10.2478/euco-2014-0017.

[44] Tömmel, I. (1998). Transformation of governance: The European Commission's strategy for creating a 'Europe of the regions'. Regional \& Federal Studies 8(2), 52-80. DOI: $10.1080 / 13597569808421051$.

[45] Trouvé, A., Berriet-Solliec, M. \& Lépicier, D., eds. (2013). Le développement rural en Europe: quel avenir pour le deuxième pilier de la Politique Agricole Commune? Bruxelles: P.I.E. Peter Lang.

[46] Di Rienzo, M., Di Napoli, R., Masani, L. \& Conterio, M. (2012). L’Approccio Leader. Approccio Leader, Speciale - I Gal si presentano al Salone del Gusto.

[47] Metis Gmbh, AEIDL, CEU, 2010. Ex-post evaluation of LEADER+. Vienna. 
[48] OECD (Organization for Economic Co-operation and Development) (2009) Italy, OECD, Paris, p. 123-124.

[49] Thelen, W. (1999). The Hessen regional programme for rural areas and LEADER, Contribution to the LEADER Seminar in Gesves (Wallonie-B) Internetseite Rural Europe, European LEADER Observatory: http://ec.europa.eu/agriculture/rur/LEADER2/ruralen/plr/mainstream/index.htm\#4-2. Citation at 20. 8. 2014. 